\title{
PERBANDINGAN JUMLAH KECELAKAAN LALULINTAS JALAN ANTAR INSTANSI TERKAIT DI INDONESIA
}

\author{
Budi Hartanto Susilo ${ }^{[1]}$, Firman ${ }^{[2]}$ \\ ${ }^{[1]}$ Dosen tetap Teknik Sipil Universitas Kristen Maranatha, Bandung \\ ${ }^{[2]}$ Alumnus D-III Teknik Sipil Universitas Katolik Parahyangan, Bandung
}

\begin{abstract}
ABSTRAK
Kinerja keselamatan lalulintas jalan di Indonesia berada pada peringkat sembilan dari sepuluh negara ASEAN (ADB-ASEAN, 1999). Penanganan masalah keselamatan akibat kecelakaan lalulintas jalan di Indonesia belum memberi hasil yang baik. Oleh karena itu, Indonesia perlu bekerja keras dan segera melakukan berbagai program serta tindakan untuk meningkatkan keselamatan lalulintas. Suatu kajian tentang faktor konversi data kecelakaan fatal pernah dilakukan di Bandung pada tahun 1996 (Susilo et al). Metode yang digunakan pada studi ini adalah membandingkan data jumlah korban meninggal yang ada di rumah sakit dengan data yang ada di kepolisian untuk kecelakaan yang sama. Lima rumah sakit yang menjadi obyek pengamatan adalah Hasan Sadikin, Boromeus, Imannuel, Advent, dan AlIslam. Studi ini menghasilkan suatu faktor konversi yang mempunyai rentang antara 1,15 hingga 1,35, dan studi ini merekomendasikan faktor konversi sebesar 1,25. Rasio antara jumlah kecelakaan yang ada di PT. Jasa Raharja (36.000) terhadap jumlah kecelakaan yang ada pada Kepolisian Republik Indonesia (28.470) adalah 1,26. Angka ini mendekati faktor konversi data hasil studi Susilo et al (1996). Bila faktor konversi yang digunakan adalah 1,25 dengan data kecelakaan mati 28.470 jiwa (POLRI, 2006) dan diasumsikan jumlah penduduk Indonesia 220 juta, serta rasio kepemilikan kendaraan bermotor adalah 1 : 20 maka akan didapat jumlah kecelakaan mati sebanyak 35.588 jiwa dengan tingkat kecelakaan fatal sebesar 33 jiwa per 10.000 kendaraan $(=(28.470 \mathrm{x} 1,25)$ : $(220$ juta $\mathrm{x}$ $1 / 20$ x 1/10000)). Berdasarkan tabel peringkat kecelakaan fatal dari Fjellstrom (2002) maka Indonesia menduduki peringkat ke-14 setelah Botswana atau peringkat ketiga di Asia setelah Bangladesh dan Syria. Data yang diperoleh dari instansi terkait seperti instansi kepolisian dalam hal ini ada tiga instansi, antara lain instansi kepolisian (POLDA dan Polwitabes), Jasa Raharja dan Dinas Kesehatan. Data dari ketiga instansi tersebut diperlukan untuk dikelompokkan dan dibandingkan sehingga dapat dicari suatu faktor yang bisa menghubungkan data-data yang ada sebagai suatu kesatuan pangkalandata yang seragam (uniform). Oleh karena itu diperlukan suatu faktor konversi untuk menyeragamkan data yang ada berdasarkan time series. Selanjutnya data yang sudah lengkap dapat dibuatkan suatu persamaan untuk memprediksi kecelakaan yang akan terjadi di masa mendatang. Hal ini sudah dilakukan oleh peneliti-peneliti sebelumnya seperti Smeed dan Andreassen.
\end{abstract}

Kata kunci: kecelakaan lalulintas jalan, tingkat kecelakaan, data kecelakaan, dan faktor konversi.

\begin{abstract}
The performance of road traffic safety in Indonesia is not good. It is at ninth rank from ten of ASEAN Countries (ADB - ASEAN 1999). The handling of problems is not give yet good solutions. Indonesia has to work hard to carry out the problems by using the programs to raise-up the road safety. There was a study in Bandung about conversion factor of road traffic fatal accident in year 1996 (Susilo et al). The used method in this study is to compare the number of death in several hospital with the number of death of police agency at the same period and same study area. The result is a conversion factor of 1.25 with rank 1.15 - 1.35. If the conversion factor used is 1.25 with number of death 28,470 people (police agency, 2006) and assumed the population of Indonesia is 220 million people and car ownership ratio 1:20 than the number of that 35,588 people with fatal accident rate 33 people per 10,000 vehicles. Based on the table of fatal accident rank from GTZ (Fjellstrom, 2002), so Indonesian position at 14 level after Botswana or third rank in Asia after Bangladesh and Syria. There are three agencies whose take the accident data, Police Agency (Polda and Polwil), Insurance agency (Asuransi
\end{abstract}


Jasa Raharja) and Health Agency (Dinas Kesehatan). Commonly their data is different one to other, because of differential of definition, perception, instruction, policy and interest of each agency. It is needed to be uniform data by classification and comparison of their data. By using the conversion factors their data to uniform.

Key words: road traffic accident, accident rate, data of accident, and conversion factors.

\section{PENDAHULUAN}

\subsection{Latar Belakang}

Kinerja keselamatan lalulintas jalan di Indonesia berada pada peringkat sembilan dari sepuluh negara ASEAN (ADB-ASEAN, 1999). Penanganan masalah keselamatan akibat kecelakaan lalulintas jalan di Indonesia belum memberi hasil yang baik. Oleh karena itu, Indonesia perlu bekerja keras dan segera melakukan berbagai program serta tindakan untuk meningkatkan keselamatan lalulintas. Indonesia masih kurang serius dalam menangani keselamatan lalulintas, misalnya disiplin berlalulintas yang rendah, kesadaraan akan keselamatan yang rendah, kompetensi petugas bidang keselamatan yang belum memadai, penegakan hukum yang belum menimbulkan efek jera, dan sistem informasi yang belum memadai pula (Pikiran Rakyat, 2006).

Khusus untuk pangkalan data kecelakaan di Indonesia, belum adanya koordinasi antarinstansi menyebabkan data korban kecelakaan lalulintas antar-instansi berbeda-beda. Belum lagi, tidak lancarnya sistem informasi membuat pencatatan korban kecelakaan pun tidak akurat. Dibandingkan dengan negara ASEAN lainnya, Indonesia merupakan negara yang paling buruk dalam sistem pencatatan informasinya. Ini terbukti dari perbedaan antara data korban mati yang dilaporkan dengan data sebenarnya (Dephub, 2004).

\subsection{Maksud dan tujuan}

Maksud dari kegiatan ini adalah melakukan perbandingan data - data kecelakaan yang

ada di instansi - instansi terkait seperti instansi kepolisian, Jasa Raharja, dan Dinas Kesehatan.

Berdasarkan pemahaman di atas, tujuan yang ingin dicapai pada kajian ini adalah sebagai berikut:

1. Meninjau kecenderungan jumlah kecelakaan lalulintas pada suatu periode waktu tertentu termasuk kecenderungan jumlah korban mati akibat kecelakaan lalulintas.

2. Membuat metode pengembangan pengelolaan data dengan menggunakan metode penyeragaman yang pada gilirannya akan menghasilkan pangkalandata yang seragam. 
3. Mengembangkan pangkalandata kecelakaan lalulintas jalan yang terpadu sebagai landasan informasi bagi kegiatan peningkatan keselamatan lalulintas jalan di Indonesia.

\subsection{Batasan Studi}

Studi ini dilaksanakan dengan beberapa pembatasan. Pembatasan yang dilakukan meliputi jenis data yang dikumpulkan, cara pengumpulan data, wilayah studi, serta durasi waktu data yang akan dianalisis. Pembatasan masalah tersebut antara lain:

1. Data yang dikumpulkan merupakan data sekunder. Data tersebut mencakup level Provinsi dan Kabupaten / Kota untuk instansi-instansi terkait, seperti POLRI, Dephub, Depkes / rumah sakit, atau Asuransi Jasa Raharja.

2. Wilayah studi difokuskan di Provinsi Jawa Barat, yaitu level Provinsi dan Kabupaten / Kota secara berjenjang atau hirarki. Provinsi Jawa Barat dipilih sebagai wilayah studi karena karakteristik permasalahan yang dimilikinya, seperti tingginya jumlah dan jenis kecelakaan yang terjadi, geografi jalan, dan arus lalulintas yang bervariasi.

3. Studi ini tidak membahas sistem informasi data kecelakaan lalulintas jalan sebagai suatu proses. Pembahasan difokuskan pada cara penyeragaman data.

4. Data kecelakaan yang dibahas adalah data korban mati. Data ini dipilih karena data korban mati mempunyai catatan yang lebih baik di instansi kepolisian, dinas kesehatan/rumah sakit, dan asuransi Jasa Raharja.

\section{DEFINISI KEBERADAAN KECELAKAAN LALULINTAS DI INDONESIA}

Kadiyali (1975) dalam Muhtar et al (2007) mendefinisikan kecelakaan lalulintas jalan (road accident) sebagai tabrakan, overtuning, atau selip yang terjadi di jalan terbuka dan melibatkan lalulintas umum yang menyebabkan luka, kematian / fatal, atau kerusakan pada kendaraan (kerugian material).

Pasal 93 Peraturan Pemerintah No. 43 Tahun 1993 tentang Prasarana dan Lalulintas Jalan merupakan cerminan dari Kecelakaan Lalulintas Jalan di Indonesia. Pasal tersebut mendefinisikan kecelakaan lalulintas sebagai suatu peristiwa di jalan yang tidak disangkasangka dan tidak disengaja, yang melibatkan kendaraan dengan atau tanpa pemakai jalan lainnya, serta mengakibatkan korban manusia atau kerugian harta benda. Korban kecelakaan lalulintas dapat berupa korban mati (fatal), korban luka berat (serious injury), atau korban luka ringan (slight injury). Pengertian dari korban kecelakaan lalulintas jalan adalah sebagai berikut: 
1. Korban mati adalah korban yang dipastikan mati sebagai akibat suatu kecelakaan lalulintas dalam waktu paling lama 30 hari sejak kejadian tersebut.

2. Korban luka berat; merupakan korban yang karena luka-lukanya menderita cacat tetap atau harus dirawat. Arti cacat tetap adalah bila suatu anggota badan hilang atau tidak dapat digunakan sama sekali dan tidak dapat pulih selama-lamanya.

3. Korban luka ringan adalah korban selain korban mati dan korban luka berat.

International Road Traffic and Accident Database (IRTAD, 1998) memberikan definisi tentang kecelakaan dan tingkat keparahannya sebanyak 27 buah sesuai dengan jumlah negara yang termasuk dalam OECD (Organization for Economic Co-operation and Development). Sebagai contoh adalah korban luka berat atau korban yang dirumah-sakitkan di Inggris adalah korban yang menginap di rumah sakit untuk pemeriksaan atau yang mengalami retak/patah tulang, gegar-otak, luka-dalam, remuk/hancur bagian tubuhnya, beberapa luka sobek, beberapa benturan yang perlu pengobatan, dan atau luka yang membawa kematian setelah 30 hari dari kejadian. Korban luka ringan di Inggris adalah korban yang mengalami keseleo, luka memar, luka tergores ringan atau lecet-lecet dan kaget (shock) ringan yang perlu ditenangkan.

\section{DATA KECELAKAAN LALULINTAS JALAN}

John F. Kennedy telah memberi perhatian terhadap kecelakaan lalulintas di jalan dengan pernyataan bahwa "Traffic accidents are one of the greatest, perhaps the greatest, national public health problems”. WHO (1999) memprediksi bahwa ranking kecelakaan fatal di jalan sebagai penyebab kematian akan meningkat dalam periode 20 tahun mendatang, yaitu dari peringkat sembilan menjadi peringkat tiga pada tahun 2020, seperti ditunjukkan pada Tabel 1.

Perbandingan Jumlah Kecelakaan Lalulintas Jalan Antar Instansi Terkait di Indonesia 
Tabel 1. Daftar Peringkat 10 Hal Penyebab Kematian Terbesar (WHO, 2004).

\begin{tabular}{ll}
\hline Penyakit atau Luka tahun 1998 & Penyakit atau Luka tahun 2020 \\
\hline 1. Infeksi Saluran Pernapasan & 1. Penyakit Serangan Jantung \\
2. HIV / AIDS & 2. Depresi Berat \\
3. Kondisi Hamil Sebelum Melahirkan & 3. Luka Kecelakaan Lalulintas Jalan \\
4. Penyakit Diare & 4. Penyakit Stroke \\
5. Depresi Berat & 5. Penyakit Paru - Paru Kronis \\
6. Penyakit Serangan Jantung & 6. Penyakit Saluran Pernapasan \\
7. Penyakit Stroke & 7. TBC \\
8. Malaria & 8. Perang \\
9. Luka Kecelakaan Lalulintas Jalan & 9. Penyakit Diare \\
10. Penyakit Paru - Paru Kronis & 10. HIV / AIDS \\
\hline
\end{tabular}

Setiap hari terjadi 3.000 kematian di jalan-jalan di dunia dan 30.000 lainnya menderita luka-luka dan cacat. Akumulasi jumlah tersebut menyatakan bahwa lebih dari satu juta orang tewas dan antara 20 juta hingga 50 juta orang menderita luka-luka dan cacat dalam kecelakaan lalulintas jalan setiap tahunnya (Tanaboriboon, 2004). Data yang ada juga menunjukkan bahwa tingkat kecelakaan lalulintas di negara-negara berkembang meningkat dari waktu ke waktu, sedangkan tingkat kecelakaan lalulintas di negara-negara maju cenderung mengalami penurunan. Hampir 86\% kecelakaan tersebut terjadi di negara-negara berkembang meskipun negara-negara ini hanya memiliki 30\% kendaraan di dunia. Gambar 1. menunjukkan kecenderungan jumlah korban mati yang tercatat di kepolisian di negaranegara ASEAN. Enam negara menunjukkan kecenderungan naik dan empat negara lainnya termasuk Indonesia menunjukkan kecenderungan turun.

Gambaran kecenderungan dan jumlah korban mati ini akan berbeda bila digunakan data prakiraan yang terjadi, seperti yang terlihat pada Tabel 2 Jumlah korban mati di Indonesia menjadi 30.464 orang atau hampir empat kali dari nilai yang tercatat di kepolisian (WHO, 2004). Hal ini tidak akan terjadi sekiranya sistem pencatatannya baik seperti di Malaysia, yang mempunyai angka yang sama baik yang tercatat di kepolisian maupun nilai estimasinya.

Agung (2002) menyatakan jumlah kecelakaan lalulintas di Indonesia relatif tinggi. Hal ini tidak berarti bahwa tidak ada upaya untuk mengurangi jumlah kecelakaan lalulintas tersebut. Ada beberapa alasan mengapa upaya yang dilakukan kurang berhasil. Satu di 
antaranya adalah kurang atau tidak adanya upaya yang terintegrasi dalam menyelesaikan permasalahan yang ada.

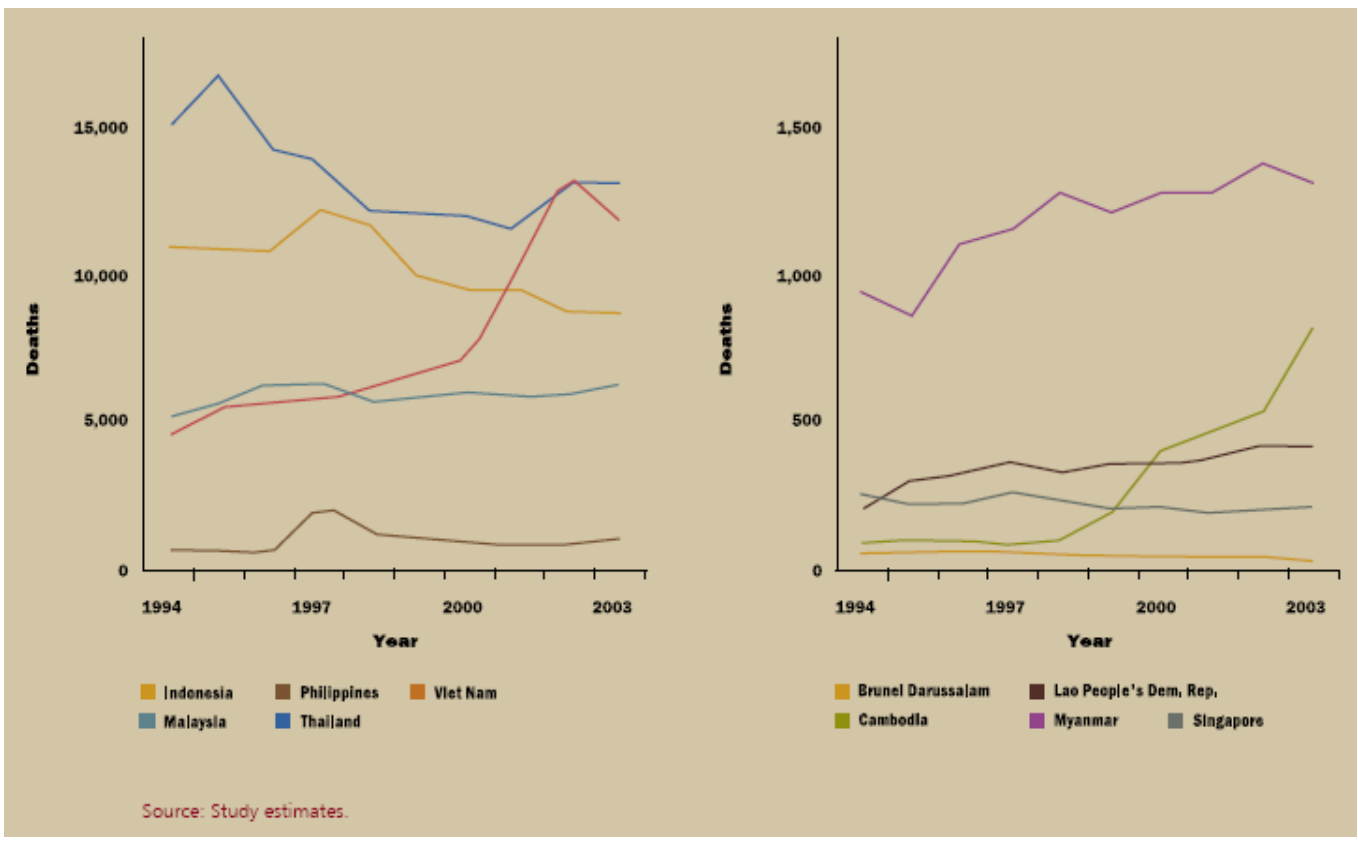

Gambar 1. Kecenderungan Jumlah Korban Mati Kecelakaan Lalulintas Jalan yang Tercatat di Kepolisian di Negara-negara ASEAN (ADB, 2003).

Tabel 2. Jumlah Korban Mati dan Luka yang Tercatat di Kepolisian dan yang di Estimasi di Negara - Negara ASEAN (ADB, 2003).

\begin{tabular}{|c|c|c|c|c|}
\hline \multirow[b]{2}{*}{ Country } & \multicolumn{2}{|c|}{ Police-Reported } & \multicolumn{2}{|c|}{ Estimated } \\
\hline & Deaths & Doluries & Deaths & Infurles \\
\hline Brunei Darussalam & 28 & 645 & 28 & 1,273 \\
\hline Cambodia & 824 & 6,329 & 1,017 & 20,340 \\
\hline Indonesla & 8,761 & 13,941 & 30,464 & $2,550,000$ \\
\hline $\begin{array}{l}\text { Lao People's Democ } \\
\text { Republlc }\end{array}$ & 415 & 6,231 & 581 & 18,690 \\
\hline Malaysla & 6,282 & 46,420 & 6,282 & 46,420 \\
\hline Myanmar & 1,308 & 9,299 & 1,308 & 45,780 \\
\hline Philippines & 995 & 6,790 & 9,000 & 493,970 \\
\hline SIngapore & 211 & 7,975 & 211 & 9,072 \\
\hline Thalland & 13,116 & 69,313 & 13,116 & $1,529,034$ \\
\hline Vlet Nam & 11,319 & 20,400 & 13,186 & 30,999 \\
\hline Total ASEAN & 43,259 & 187,343 & 75,193 & $4,745,578$ \\
\hline
\end{tabular}




\subsection{Faktor Konversi}

Sebagai dasar informasi, seyogyanya data kecelakaan itu perlu mempunyai sifat-sifat yang ajeg, tidak gampang berubah, seragam, mudah diakses dan dapat ditransfer sehingga berguna bagi banyak instansi dan kalangan yang membutuhkannya, tanpa memperdebatkan lagi keabsahan dan keterandalannya. Untuk mendapatkan data yang seragam diperlukan suatu metode. Menurut IRTAD (2004), karena ketidaksamaan periode atau saat korban mati akibat kecelakaan, maka diperlukan suatu faktor koreksi untuk menentukan jumlah kecelakaan mati menurut definisi internasional. (yang menggunakan waktu standar 30 hari). Faktor konversi yang digunakan dalam pangkalandata IRTAD, berupa faktor koreksi, dapat berupa penambahan atau pengurangan nilai standar (100\%), tergantung durasi waktu yang dianut oleh negara tersebut, mulai dari terjadinya kecelakaan sampai meninggalnya si korban. Faktor koreksi dari negara-negara tersebut adalah sebagai berikut:

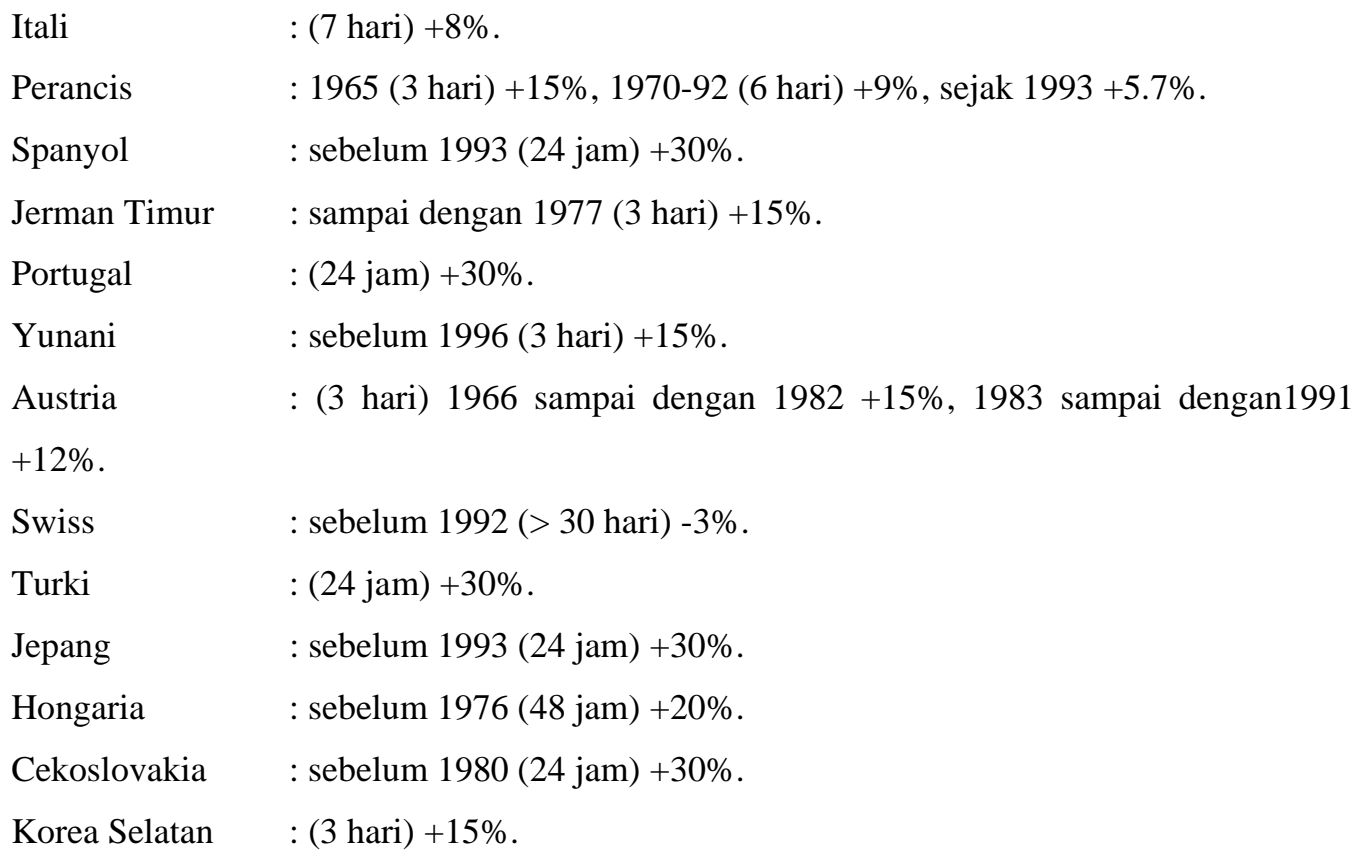

Bagi negara yang mencantumkan batasan waktu tahunnya, berarti sesudah tahun tersebut, negara itu mulai menganut definisi Internasional. Faktor konversi mati dalam waktu 6 hari sejak terjadinya kecelakaan lalulintas sebesar 9\% dinyatakan oleh Hobbs (1979),O’Flaherty (1997).

Suatu kajian tentang faktor konversi data kecelakaan fatal pernah dilakukan di Bandung pada tahun 1996 (Susilo et al). Metode yang digunakan pada studi ini adalah 
membandingkan data jumlah korban meninggal yang ada di rumah sakit dengan data yang ada di kepolisian untuk kecelakaan yang sama. Lima rumah sakit yang menjadi obyek pengamatan adalah Hasan Sadikin, Boromeus, Imannuel, Advent, dan Al-Islam. Studi ini menghasilkan suatu faktor konversi yang mempunyai rentang antara 1,15 hingga 1,35, dan studi ini merekomendasikan faktor konversi sebesar 1,25. Bila nilai tersebut digunakan, maka jumlah korban mati akibat kecelakaan lalulintas di Indonesia (dihitung dari saat terjadinya kecelakaan hingga 30 hari setelah kecelakaan tersebut) akan meningkat sebesar 25\%. Perubahan nilai inilah yang dimaksud dengan menginternasionalisasikan data kecelakaan lalulintas jalan di Indonesia.

\subsection{Peringkat Dunia Tingkat Kecelakaan Indonesia}

Rasio antara jumlah kecelakaan yang ada di PT. Jasa Raharja (36.000) terhadap jumlah kecelakaan yang ada pada Kepolisian Republik Indonesia (28.470) adalah 1,26. Angka ini mendekati faktor konversi data hasil studi Susilo et al (1996). Bila faktor konversi yang digunakan adalah 1,25 dengan data kecelakaan mati 28.470 jiwa (POLRI, 2006) dan diasumsikan jumlah penduduk Indonesia 220 juta, serta rasio kepemilikan kendaraan bermotor adalah 1 : 20 maka akan didapat jumlah kecelakaan mati sebanyak 35.588 jiwa dengan tingkat kecelakaan fatal sebesar 33 jiwa per 10.000 kendaraan (= $(28.470 \times 1,25)$ : (220 juta x 1/20 x 1/10000)). Berdasarkan tabel peringkat kecelakaan fatal dari Fjellstrom (2002) maka Indonesia menduduki peringkat ke-14 setelah Botswana atau peringkat ketiga di Asia setelah Bangladesh dan Syria, seperti terlihat pada Gambar 2 sebagai perbandingan, negara di Asia yang mempunyai tingkat kecelakaan terkecil adalah Jepang, yaitu 1 jiwa per 10.000 kendaraan. Jepang juga menduduki peringkat ketiga terkecil di dunia, setelah Iceland dan Norwegia. 


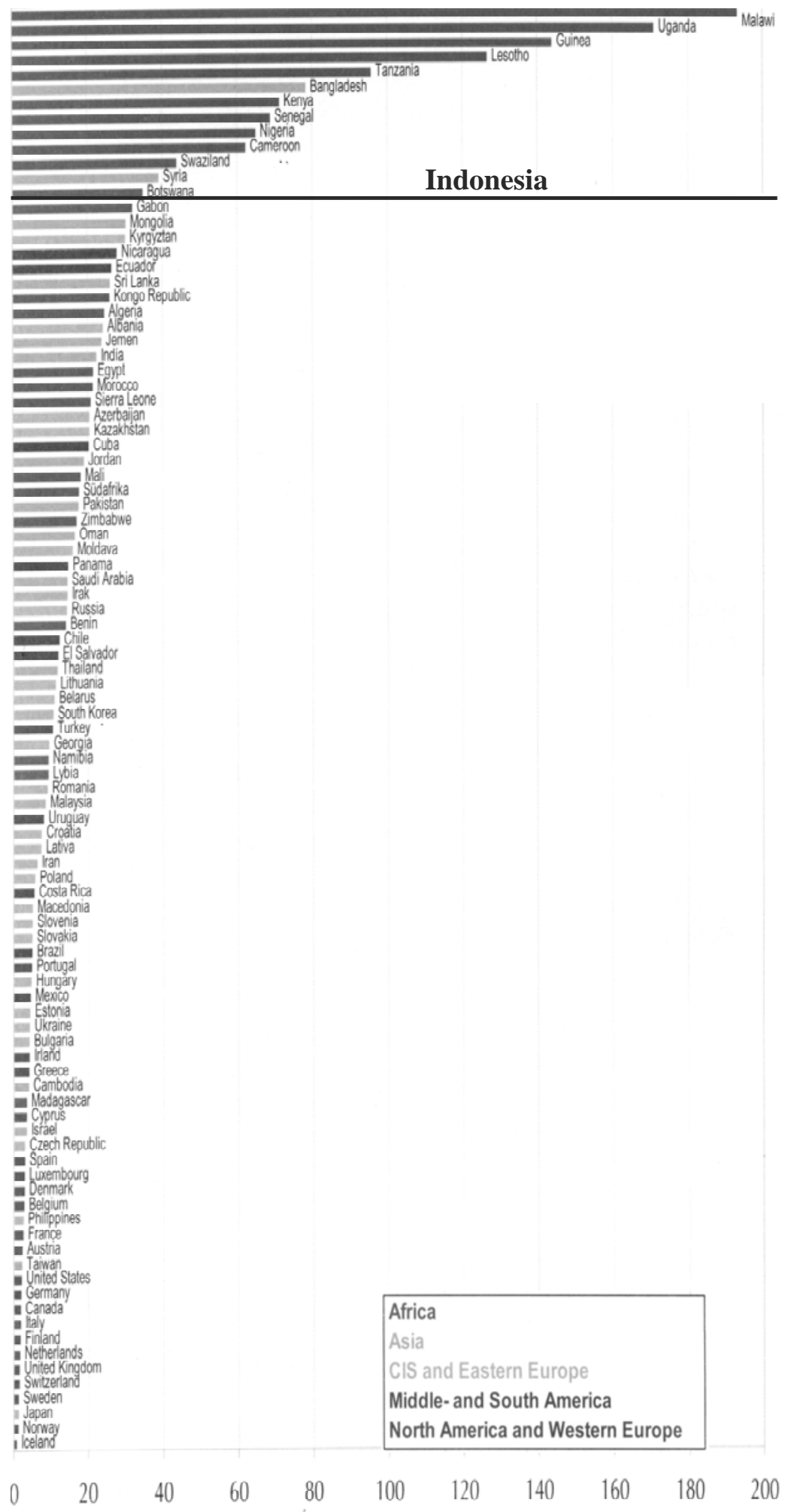

Korban Mati dalam kecelakaan lalulintas per 10000 


\section{PEMBAHASAN DAN ANALISA}

\subsection{Sumber Data Kecelakaan di Indonesia}

Data yang diperoleh dari instansi terkait seperti instansi kepolisian dalam hal ini ada tiga instansi, antara lain instansi kepolisian (POLDA dan Polwitabes), Jasa Raharja dan Dinas Kesehatan. Data dari ketiga instansi tersebut diperlukan untuk dikelompokkan dan dibandingkan sehingga dapat dicari suatu faktor yang bisa menghubungkan data-data yang ada sebagai suatu kesatuan pangkalandata yang seragam (uniform).

Penyeragaman data kecelakaan lalulintas di Indonesia dilakukan karena data kecelakaan yang ada terdapat perbedaan, baik jumlah kejadian maupun jumlah korban dan nilai kerugian material. Data kecelakaan lalulintas jalan yang diperoleh dari POLDA Jawa Barat pada kurun waktu (1993-2007) memperlihatkan terjadinya peningkatan jumlah kejadian kecelakaan sebanyak 878 kejadian, jumlah korban MD mengalami penurunan sebanyak 53 orang, jumlah korban Luka Berat mengalami peningkatan sebanyak 297 orang, jumlah korban Luka Ringan peningkatan sebanyak 651 orang, seperti yang terlihat pada Tabel 3.

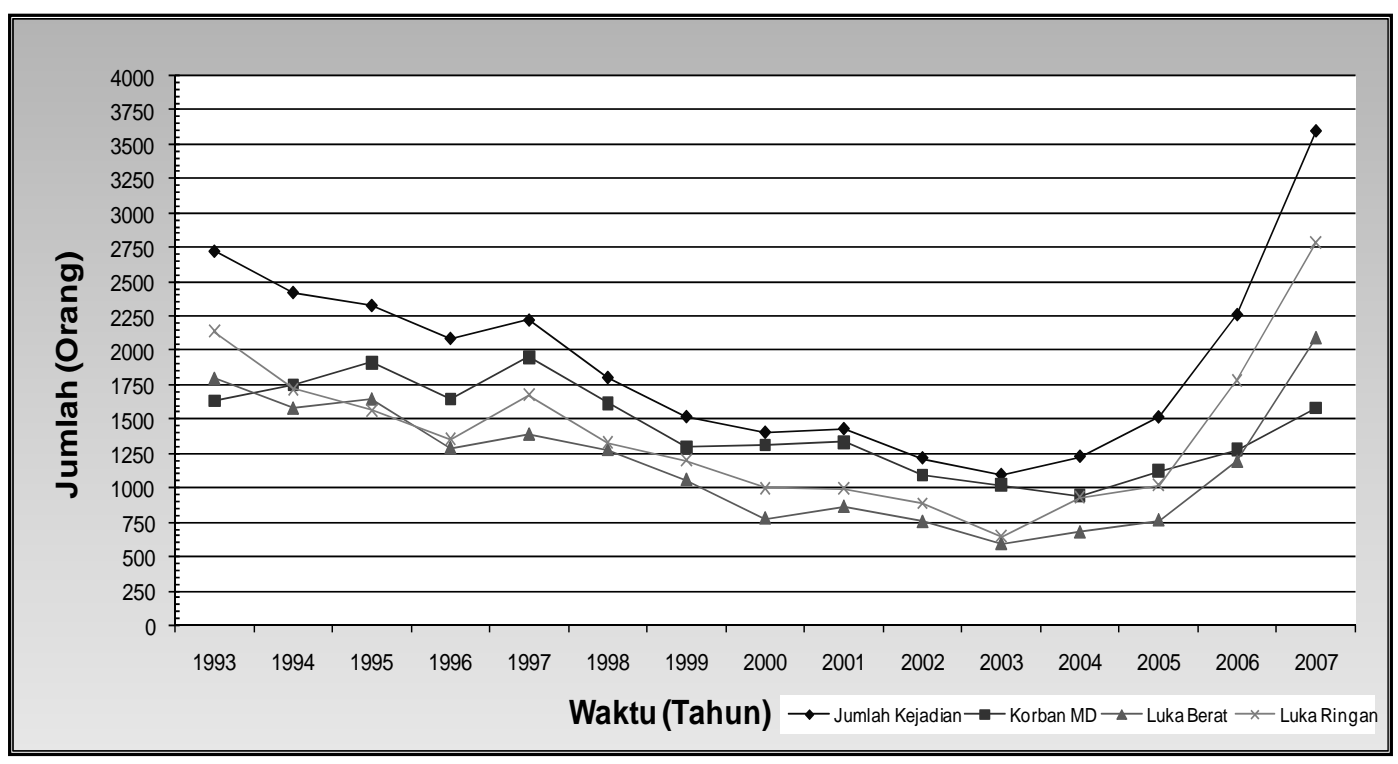

\section{Tabel 3. Data Kecelakaan Lalulintas Jalan di Indonesia Tahun 1993-2007 (POLDA Jawa Barat, 2008).}

Data kecelakaan yang diperoleh dari Polwiltabes Bandung pada kurun waktu (20032008), menunjukkan pada tahun 2007 mengalami peningkatan yang signifikan. Pada Tabel 5 terlihat jumlah kejadian kecelakaan meningkat sebanyak 625 kejadian, jumlah korban MD meningkat sebanyak 40 orang, jumlah korban Luka Berat meningkat sebanyak 159 orang, 
korban Luka Ringan meningkat sebanyak 427 orang. Pada Tabel 5 berdasarkan data yang didapat dari instansi Jasa Rahara Provinsi Jawa Barat terlihat jumlah kejadian kecelakaan mengalami peningkatan sebanyak 568 kejadian, jumlah korban MD mengalami peningkatan sebesar 630 korban, jumlah korban Luka Berat mengalami penurunan sebesar 7 orang, jumlah korban Luka Ringan sebesar 55 orang.

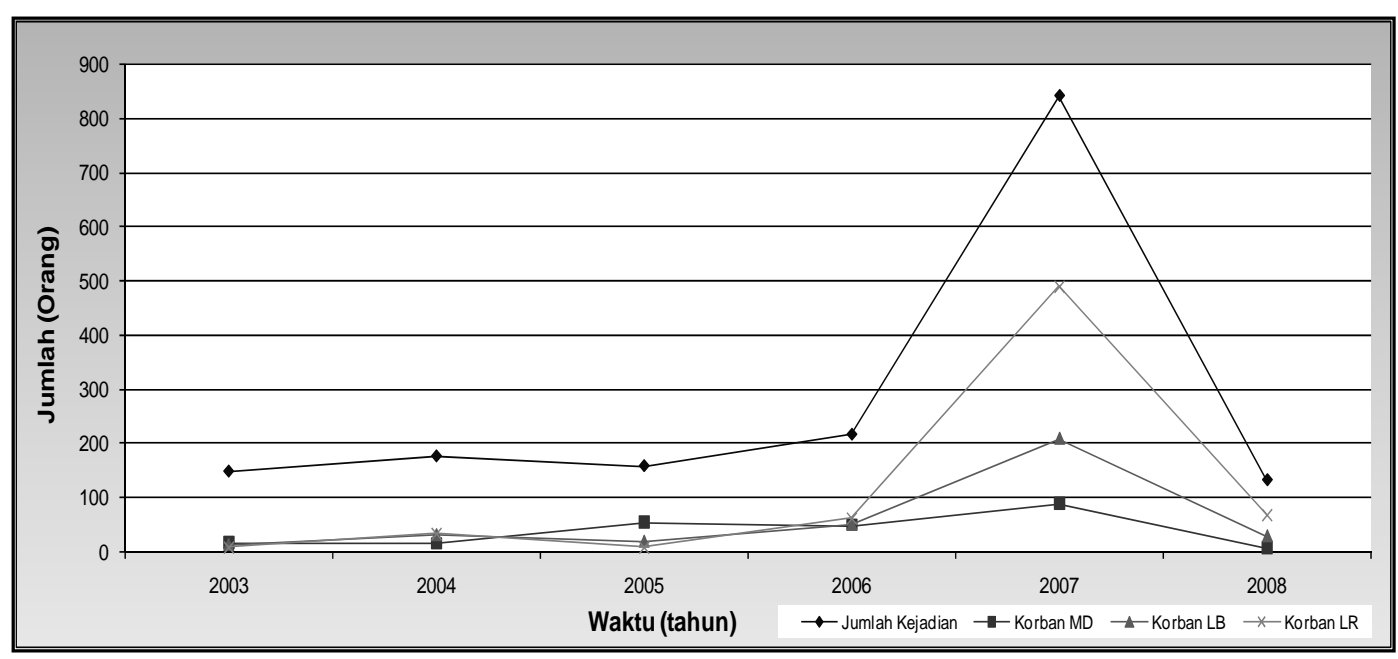

Tabel 4. Data Kecelakaan Lalulintas Jalan di Indonesia Tahun 2003-2008 (Polwitabes Bandung, 2008).

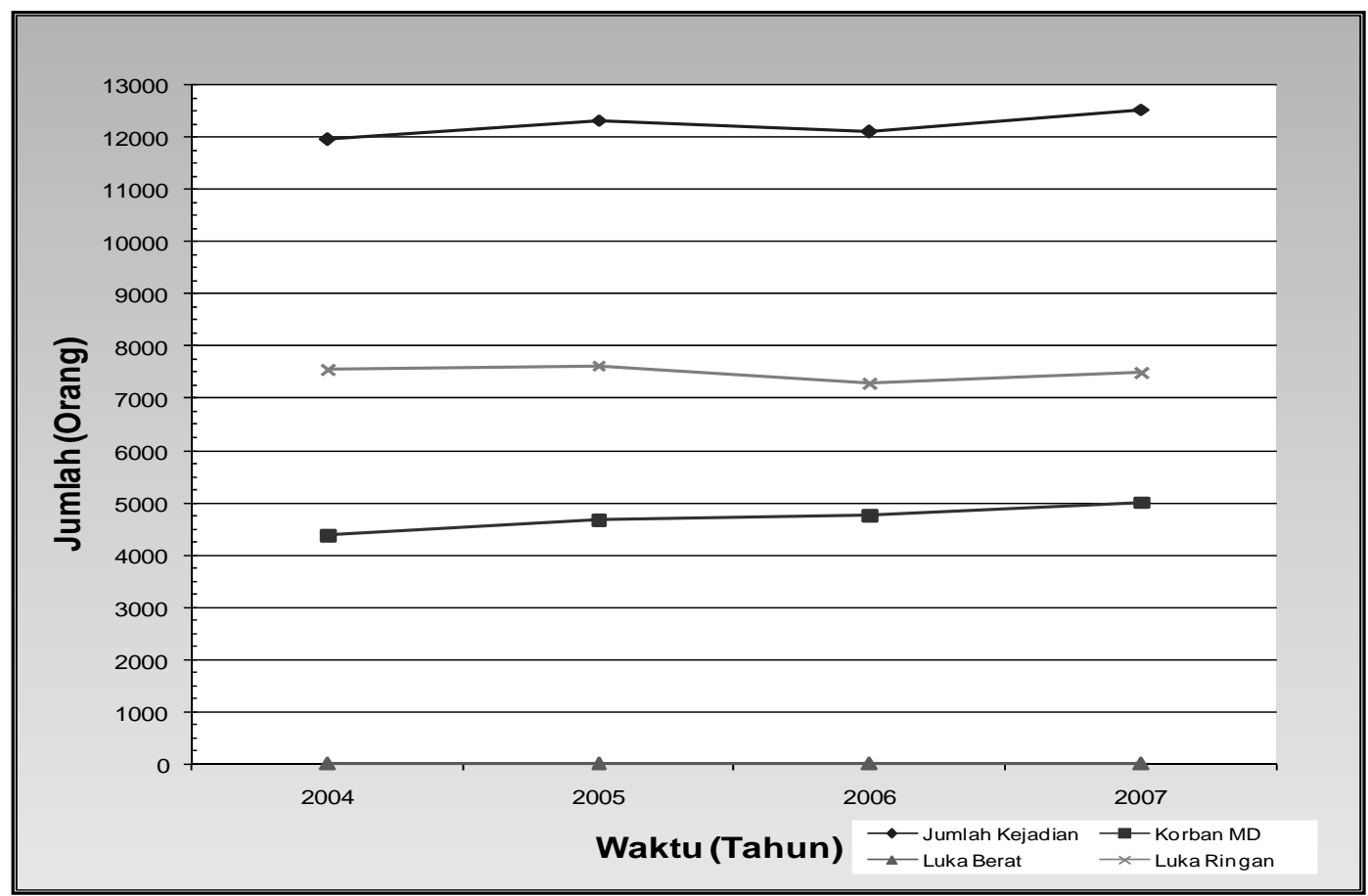

Tabel 5. Data Kecelakaan Lalulintas Jalan di Indonesia Tahun 2004-2007 (Jasa Raharja Provinsi Jawa Barat, 2008). 
Tabel 6 memperlihatkan jumlah kejadian kecelakaan mengalami peningkatan sebanyak 568 kejadian, jumlah korban MD naik sebesar 630 korban, jumlah Luka Berat turun sebesar 7 korban, jumlah Luka Ringan turun sebesar 55 korban.

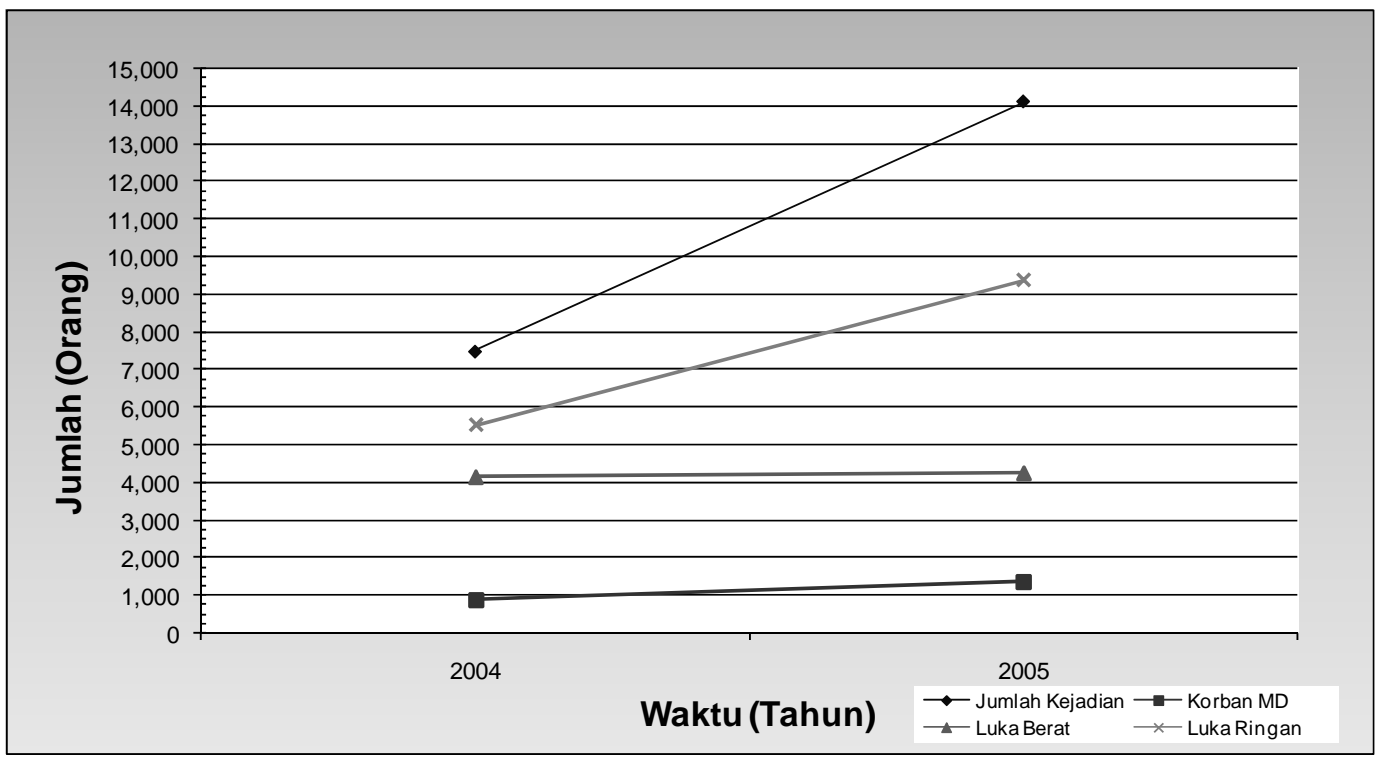

Tabel 6. Data Kecelakaan Lalulintas Jalan di Indonesia Tahun 2004-2005 (Dinas Kesehatan Provinsi Jawa Barat, 2008).

Dari data kecelakaan di atas dapat diketahui bahwa pangkalandata kecelakaan dari masing-masing instansi terdapat perbedaan dan tidak seragam berdasarkan time series kejadian. Hal ini dikarenakan keterbatasan data yang terekam antar-instansi terkait dan perbedaan sistem klasifikasi pencatatan jumlah korban. Oleh karena itu diperlukan suatu faktor konversi untuk menyeragamkan data yang ada berdasarkan time series. Selanjutnya data yang sudah lengkap dapat dibuatkan suatu persamaan untuk memprediksi kecelakaan yang akan terjadi di masa mendatang. Hal ini sudah dilakukan oleh peneliti-peneliti sebelumnya seperti Smeed dan Andreassen.

\subsection{Penyesuaian Data Kecelakaan di Indonesia}

Data yang bersumber sama dari POLRI akan menjadi sangat berbeda bila dibandingkan dengan data yang bersumber dari Jasa Raharja. Permasalahan ini tidak akan tuntas mengingat definisi dari tingkat keparahan korban adalah berbeda. Pemahaman luka mati bagi POLRI adalah korban yang mati di tempat sedangkan pemahaman luka mati bagi Jasa Raharja adalah korban yang mati sejak kejadian sampai 6 bulan kemudian sebagai batas waktu claim. Berdasarkan data yang dikeluarkan oleh PT. Jasa Raharja (Pikiran Rakyat, 
2006) yang diakses tanggal 15 Nopember 2007, pada tahun 2005 terdapat 36.000 orang meninggal karena kecelakaan lalulintas. Untuk tahun yang sama, Kepolisian Republik Indonesia menyatakan terjadi korban meninggal akibat kecelakaan lalulintas sebanyak 28.470 jiwa. Perbandingan jumlah kecelakaan pada Jasa Raharja terhadap jumlah kecelakaan pada kepolisian adalah $36.000: 28.470=1,26$. Rupanya faktor perbandingan ini tidak beda jauh dari hasil studi yang pernah dilakukan oleh Jurusan Teknik Sipil UKM dengan rentang nilai konversi tingkat kecelakaan adalah 1,25 antara data rumah sakit terhadap data kepolisian di kota Bandung.

\section{PENUTUP}

\subsection{Kesimpulan}

Data yang diperoleh dari instansi terkait seperti instansi kepolisian dalam hal ini ada tiga instansi, antara lain instansi kepolisian (POLDA dan Polwitabes), Jasa Raharja dan Dinas Kesehatan. Data dari ketiga instansi tersebut diperlukan untuk dikelompokkan dan dibandingkan sehingga dapat dicari suatu faktor yang bisa menghubungkan data-data yang ada sebagai suatu kesatuan pangkalandata yang seragam (uniform).

Berdasarkan data kecelakaan dari instansi kepolisian, Jasa Raharja, dan Dinas Kesehatan dapat diketahui bahwa pangkalandata kecelakaan dari masing-masing instansi terdapat perbedaan dan tidak seragam berdasarkan time series kejadian. Hal ini dikarenakan keterbatasan data yang terekam antar-instansi terkait dan perbedaan sistem klasifikasi pencatatan jumlah korban. Oleh karena itu diperlukan suatu faktor konversi untuk menyeragamkan data yang ada berdasarkan time series. Selanjutnya data yang sudah lengkap dapat dibuatkan suatu persamaan untuk memprediksi kecelakaan yang akan terjadi di masa mendatang. Hal ini sudah dilakukan oleh peneliti-peneliti sebelumnya seperti Smeed dan Andreassen.

Data yang bersumber sama dari POLRI akan menjadi sangat berbeda bila dibandingkan dengan data yang bersumber dari Jasa Raharja. Permasalahan ini tidak akan tuntas mengingat definisi dari tingkat keparahan korban adalah berbeda. Pemahaman luka mati bagi POLRI adalah korban yang mati di tempat sedangkan pemahaman luka mati bagi Jasa Raharja adalah korban yang mati sejak kejadian sampai 6 bulan kemudian sebagai batas waktu claim. Berdasarkan data yang dikeluarkan oleh PT. Jasa Raharja (Pikiran Rakyat, 2006) yang diakses tanggal 15 Nopember 2007, pada tahun 2005 terdapat 36.000 orang meninggal karena kecelakaan lalulintas. Untuk tahun yang sama, Kepolisian Republik Indonesia menyatakan terjadi korban meninggal akibat kecelakaan lalulintas sebanyak 
28.470 jiwa. Perbandingan jumlah kecelakaan pada Jasa Raharja terhadap jumlah kecelakaan pada kepolisian adalah $36.000: 28.470=1,26$.

\subsection{Rekomendasi}

Dalam upaya peningkatan kualitas pangkalandata kecelakaan lalulintas di Indonesia, maka dapat dilakukan beberapa hal berikut ini:

\section{Perlunya penyesuaian pangkalandata kecelakaan lalulintas jalan di Indonesia.}

Melakukan penyeragaman pangkalandata kecelakaan lalulintas jalan di Indonesia diperlukan untuk mendapatkan suatu persamaan analisa yang dapat digunakan sebagai salah satu cara untuk mengurangi tingkat kecelakaan lalulintas jalan di Indonesia.

\section{Strategi Keselamatan Transportasi Jalan di Indonesia}

Strategi 5E (Engineering, Education, Enforcement, Emergency Medical Services, Evaluation), secara umum dikenal program penanganan keselamatan dengan 3E (Engineering, Education, Enforcement), kemudian dikembangkan di Turki dengan 5E, menambahkan betapa pentingnya Emergency Medical Services dan Evaluation sebagai E yang ke 4 dan ke 5. Mereka memprogramkan dengan aktivitas penolongan via helikopter bagi korban di kota-kota besar karena disadari setiap detik sangat berharga bagi mati hidupnya si korban. Evaluasi diperlukan dalam rangka siklus dinamis sebagai perbaikan kegiatan dari tahun ke tahun.

\section{DAFTAR PUSTAKA}

1. Direktorat Samapta Polri, (1990). Peranan POLRI Dalam Menanggulangi Daerah Rawan Dan Sistim Laporan Kecelakaan Lalulintas, Sub Direktorat Lalulintas, Jakarta.

2. Direktorat Jenderal Perhubungan Darat, (2006). Data Lalulintas Jalan di Indonesia Tahun 2002-2006, Departemen Perhubungan, Jakarta.

3. Fjellstrom, K., (2002). Urban Road Safety, GTZ - Sustainable Transport: A Sourcebook for Policy - Makers in Developing Cities, module 5b, Eschborn.

4. Hobbs, F.D., (1979). Traffic Planning \& Engineering, $2^{\text {nd }}$ ed, University of Birmingham, Pergamon Press, Oxford.

5. O’Flaherty, C.A., (1997). Transport Planning and Traffic Engineering, John Wiley \& Sons, Inc., New York, NY.

6. Pikiran Rakyat, (2006). Kecelakaan Motor Kian Meningkat, (www.pikiran-rakyat.com, diakses tanggal 12 Nopember 2007), Bandung. 
7. Pusat Penelitian dan Pengembangan Jalan dan Jembatan, (2007). Data Lalulintas Jalan di Indonesia Tahun 1971-2006, Badan Penelitian dan Pengembangan Pekerjaan Umum, Bandung.

8. Rudy, Th. Z., (2006). Integrasi Aspek Keselamatan Dalam Perencanaan Prasarana Dan Sarana Transportasi Melalui Revolusi Transportasi, Makalah, Save Indonesia From Corruption, FSTPT 17-18 November 2006, Malang.

9. Santosa, W., (2003). Strategi Peningkatan Keselamatan Lalulintas di Jalan Raya, Orasio Dies Natalies ke-43, Universitas Katolik Parahyangan, Bandung.

10. Somasundaraswaran, A. K., (2006). Accident Statistics in Srilangka, IATSS Research, Publication, Tokyo (www.iatss.or.jp, diakses tanggal 15 Nopember 2007).

11. Susilo, B.H., (2008). Internasionalisasi Data Kecelakaan Lalulintas di Indonesia, Seminar Bidang Kajian, Program Doktor Ilmu Teknik Sipil, Fakultas Teknik Universitas Katolik Parahyangan, Bandung.

12. Susilo, B.H., Sumarwan, Lesmana., (1996). Menentukan Faktor Konversi Tingkat Kecelakaan Lalulintas di Kota Bandung, Topik Khusus, Jurusan Teknik Sipil, Fakultas Teknik Universitas Kristen Maranatha, Bandung.

13. Susilo, B.H., (2008). Perbandingan Data Kecelakaan Lalulintas Jalan di Indonesia, Thailand, dan Srilangka, Seminar Bidang Kajian, Program Doktor Ilmu Teknik Sipil, Fakultas Teknik Universitas Katolik Parahyangan, Bandung.

14. Susilo, B.H., (2008). Upaya Meningkatkan Keselamatan Jalan di Indonesia, Seminar Bidang Kajian, Program Doktor Ilmu Teknik Sipil, Fakultas Teknik Universitas Katolik Parahyangan, Bandung.

15. Tanaboriboon, Y., Satiennam, T., (2004). Traffic Accidents in Thailand, IATSS Research, Publication, Tokyo (www.iatss.or.jp, diakses tanggal 15 Nopember 2007).

16. Wikimedia Foundation, Inc., (2007). Jumlah Penduduk di Bangladesh, (www.wikipedia.co.id, diakses tanggal 5 Desember 2007). 